\title{
Historical, Contemporary and Psychological Viewpoints of Teacher's Leadership
}

\author{
Elisabeta Kafia \& Silva Ibrahimi \\ Albanian University, Tirana, ALBANIA \\ Department of Psychology \\ Ervin Ibrahimi \\ Klik Ekspo Group Italia, Ancona, ITALY
}

Received: 22 October 2020 - Accepted: 15 January 2021 - Published Online: 15 April 2021

\begin{abstract}
Today, in the $21^{\text {st }}$ century, an increasing number of children and youth are facing disorders, problems and challenges regarding the nature of learning, psycho-emotional, social behavior, and further on. Today, the educational system faces not only a number of students with difficulties, but also the multitude of severity and complexity of the difficulties themselves. To successfully cope with these difficulties, immediate needs have arisen to redefine the role of the teacher as a leader in the school both in terms of teaching and in the form of reforming the roles and services that day-to-day access to students, parents and the wider community. The focus of this article is to present a broader and supportive view of the teacher leadership and its psychological and social training towards qualitative changes and ever-increasing demand for education-based training as a significant pre-requisite for EU integration.
\end{abstract}

Keywords: education leader, teacher, training, integration.

\section{Introduction}

The concept of leadership has received a wide attention initially in the studies of organizational psychology and afterwards, in clinical and psychopathologic, since the second mid of the 1900s (Quaglio, 2005). In the etymology of the recent English word "lead" stand the roots of the olden verb "læeden" that coincides with the Dutch word "leiden" and the German "leiten" as an etymological part of the Anglo-Saxon word family. This novel property "to lead" meant "...to go with..." whereas the first use of the term "leadership" meaning "being in the first place" is not recognized until the 1300 B.C. (Family Word Finder, 1978). The crucial characteristic of leadership, therefore, is the ability to organize individuals within social contexts, the mobilization of all parties involved within a relationship range between subjects who interact together in the achievement of the inquired results. The psychodynamic study of the leadership process and dynamic aspects of a leader personality are very important for the analysis and interpretation of the present work. Childhood experiences and child rearing patterns influence on how individuals mature and develop. In his psychanalytic model, Zigmund Freud and subsequently, his daughter Anna, argued for the significance of the teaching method in schools and universities as one of the great advantages psychoanalysis could give in the ordinary life (Freud, 1919). Teaching and

(C) Authors. Terms and conditions of Creative Commons Attribution 4.0 International (CC BY 4.0) apply. Correspondence: Elisabeta Kafia, Head of Department of Psychology, Albanian University, Tirana, ALBANIA. E-mail: elisabetakafia@gmail.com. 
E. Kafia, S. Ibrahimi \& E. Ibrahimi - Historical, Contemporary and Psychological Viewpoints of ...

learning methodology to Freud should be didactic through lectures, discussions and experience. In 1930 in her work "Psychoanalysis for teachers and parents, Four lectures on ...." Anna Freud wrote that the relationship which is created between teachers, child and analyst is equal to a delicate process of education; the role of psychoanalysis is to give "a helping hand" to children either to disclose their unexplored possibilities or in the full and real experience of the symptom. In her theoretical model, students projected even their worries in the endeavor to understand other through the pedagogical relation (Object Relation) but also their ordinary life frustrations. The concept of Anna Freud (1930) on education is like "an endless battle" when ego comes into the world through its defense mechanisms (perception, observation, projection, hallucination and reality testing), beyond external influences and pressures. Teachers and leaders may also be involved in dreaming and fantasies with a great covering range of defense mechanisms. Early theories of leadership and organizations were task oriented. The aim was to improve efficiency regardless human factor. Contrary to this approach, in 1960 researcher Douglas McGregor introduced the humanist leadership model when human relations and motivation for work had a crucial role. Recent studies of Robert Tannenbaum and Warren Schmid describe leadership as a continuum where several leader behavior tendencies interact (1985).

For these authors, leadership styles can be defined according to two macro-objectives that have to be followed up:

(1) coherence of outcomes and focusing in responsibilities (a characteristic feature of an autocratic or paternal leader who commands and convince);

(2) interpersonal relations and focusing in Human-resource (a characteristic feature of a democratic leader or counselor, who involves and collaborates with his or her dependents).

In their situational approach pattern, Blake and Mouton (1964) argue that there is a connection between two objectives that could be beyond a range of leadership styles:

- authoritarian-aggressive,

- assertive searcher / attentive,

- motivational,

- administrative,

- political.

Through this model the authors also defined a style to orientation, tasks and situation where the leadership style is developed. We encounter therefore an approach where there is an emphasis on the objectual relations of teacher or principals as school leaders. In their view, an executive and functional school leader must hold several responsibilities as:

- be able to organize and plan (according to case priorities and urges),

- delegate,

- be able to recognize merits and values in a sincere and insistive mode,

- be able to verify and assess,

- be able to reproject for a consistent improvement (actions appropriate in time),

- be a leader who knows what he is looking for, finds ways to achieve what he wants through maximizing resources and aiming to enhance efficiency and productivity, creates the suitable climate to motivate individual efficiency, 
- posses normative, juridical and expert knowledge, understanding and solidarity, capacities of analytical synthesis, capacity to resolve problems and take assertive and constructive decisions, they are also flexible.

School leadership must respond to the needs of changing and information asked by the society and embracing new leadership forms especially in the field of teaching leadership such as a follow-up formation, trainings and coaching (Frost \& Durrant, 2003). Formative leadership shares the responsibility of guiding to a range of individual educators in an anti-hierarchical or horizontal way. Gonzales (2004) argues that the democratization of education occurs when redefining teacher leadership as a shared form of leadership to all teachers. "Teacher leaders can transform schools in communities that prepare students to be citizens and work in a complex, technological and democratic society" (Lieberman \& Miller, 2004: 12). Researches of Silins and Mulford (2002) revealed a strong relationship between the very high scores of students and leadership used in school community, including teacher empowerment. Teachers as leaders may pursue to ask school institutions to leave structured systems and to join into improved organizational forms (Ackerman \& Mackenzie, 2006).

Let us remember at this point the continuous efforts of setting an inner and outer control of treating school as "community service" in Albania. This new formula for our country based on strong credibility in Western Countries, creates more space in fixing organizational behavior and teacher leadership. In a similar study for the fulfillment of educational reform in the United States, Glickman, Gordon, and Ross-Gordon (2001) distinguished an important characteristic related to the shared leadership. In this leadership form, teachers, according to the authors, should be active participants to be able to contribute to the school progress (Ash \& Persall, 2000; Lieberman, 1992; McCay et al., 2001). Recent data indicate that teachers choose to stay in those educational institutions that offer opportunities of collaboration and shared leadership (Harris \& Muijs, 2005).

Some of the most important dimensions of educational leadership may be summarized in the following table.

Table 1. Summarized scheme of the most core dimensions of effective educational leadership

Source: Goleman, D. (1998). “La pratica de inteligencia emocional” (adapted by the Spanish version, pp. 19)

\section{Self-Cognition}

Cognition of the self-internal status and interpersonal resources.

Emotional Cognition: Recognizing own emotions and effects

Appropriate Assessment of Self: Knowing own strength and weakness.

Self-Confidence: Security on the assessment of Self and other capacities.

\section{Autoregulation}

Control of our states, impulses and internal resources

Auto control: Capacity to manage appropriately the emotions and conflictual impulses.

Reliability: Confidentiality to the criterion of sincerity and integrity.

Integrity: Assuming the responsibilities of our personal actions

Adaptability: Flexibility to cope with change.

Innovation: Feeling comfortable and open to new ideas, approaches and information. 
E. Kafia, S. Ibrahimi \& E. Ibrahimi - Historical, Contemporary and Psychological Viewpoints of ...

\section{Motivation}

Emotional tendencies that facilitate achieving our objectives

Motivation for achieving: Improvement and satisfying criteria for excellence.

Compromise: Fulfill the objectives given by the group or organization.

Initiative: Ready to take action when is needed.

Optimism: Persistence in the consequences of objectives despite the obstacles.

\section{Social Competencies}

\section{These competencies determine the mode of relationship with others}

\section{Empathy}

Cognition of feelings, necessities and preoccupation of others.

Comprehension of others: Having the ability to capture the feelings and views of others and actively concern on things that are for interested to them.

Orientation to the service: Anticipating, recognizing, and meeting customer needs

Advantages of Diversity: Advantaging from opportunities offered by different types of people.

Political Awareness: Ability to realize the emotional currents and relationships

underlying power in a group.

\section{Social Abilities}

Ability to induce desirable responses in others.

Influence: Using effective techniques of persuasion

Communication: Sending clear and persuasive messages

Leadership: Inspiring and directing groups and persons.

Catalyzing Change: Beginning to direct changes.

Resolution of conflicts: Ability to negotiate and resolve conflicts.

Collaboration and Cooperation: Being able to work with others in achieving a common goal.

Group Skills: The ability to create group synergy in pursuing collective goals.

2. Leadership styles and teachers as school leaders

Leadership styles are related to personality, demeanor and communication patterns of leaders in guiding others for achieving personal or organizational goals. Significant research on leadership styles have been associated to self-reporting perceptions toward leader's behavior in decision-making, interpersonal relations, planning, instructions and efficient management. Among the most widely used instruments in literature to assess leadership style are: Climate Description Questionnaire (OCDQ), Leadership Behavior Description Questionnaire (LBDQ) and the Organizational Health Inventory (OHI). These instruments collect evidences on staff and members perceptions of the leadership style of directors and teachers in the dynamics of school organization. Literature, on the other hand, reveals little empirical research in understanding better why some leadership styles in certain situation are prevailing to others. Among the prime 
leadership categories in the recent literature review we encounter: charismatic leadership, social justice leadership, gender and race leadership, moral and spiritual leadership.

The four styles derived by these categories include the authoritarian, participative, transactional or transformational leadership.

Authoritarian leader employs coercive tactics to enforce rules, he or she uses Machiavellian modes to manipulate others and reward trust over merit. Control and dominance are the primary management strategies employed by authoritarian leaders. In this form of leadership, is emphasized the objectivity in the workplace and tends not to be involved to human problems and not displaying emotions or affection toward others. The $\mathrm{X}$ theory of Douglas McGregor is the leitmotiv of authoritarian style, under which people must work, closely supervised and rewarded according to their productivity. In certain situations when " $a$ commander to right the ship" is needed, authoritarian leadership style has been effective. Thus, for instance, if a director of an important institution would not have disposed some authoritarian features, likely, the direction would create space for neglect and chaos. At the same time, it is very important to know the perception of the individual over his or her own leadership style; evidences following this study suggest a progressively increasing perception over style of leadership and the reinforcement of the precepted style features.

Participative leadership moved away from the authoritarian mode of leadership to the human side of the institution. This form of leadership was initially proposed in 1930 by Mary Parker Follett, Elton Mayo, Frederick Roethlisberger et al. They argued that productivity and human relations were closely linked and directed toward informal structures and social systems. Follet thought that "managers should treat workers with dignity and change the workplace from strict authoritarian control to a collegial team concept". Authors of this stream viewed organizations as social systems where human social needs are the most important factors in motivation and efficiency.

In 1938, Douglas McGregor, Rosabeth Kanter, Tom Sergiovanni and Terry Deal, argued that shared decision-making and grouping participation in productive organizations is focused on people and their needs. These authors greatly influenced to the creation of shared decision-making in public education.

Transactional leadership tend to balance structures that meet the needs of people while things are being completed. This form of leadership requires the integration of organizational goals and expectations with the needs of individuals. As an example of representation of the transactional leadership style is the Getzels Guba (1957) social systems model. This model includes three essential dimensions: idiographic (the needs of individuals), nomothetic (the goals of the organization) and transactions between the two. Thus, the model balances the dynamics of needs and productivity of organization with needs, personality and dispositions of people working.

Eric Berne initially analyzed the relations between group and leadership as the principles of transactional analysis which includes the following elements: contingency reward, management through active exception and management through passive exception. These leaders influence the motivation of their followers by exchanging rewards to their workers for the time they are efficient with their managing needs.

Transformal leadership is called the kind of leadership style where the leader works together with employees to identify the necessary changes, develop a leadership view of change and bring to life the effects of this change. This form of leadership promotes motivation, moral and performance at work through a variety of mechanisms such as understanding self-identity and how to project this understanding into group identity, being a role model for employees, challenging employees to take control of their work, and understanding employees' strengths and 
E. Kafia, S. Ibrahimi \& E. Ibrahimi - Historical, Contemporary and Psychological Viewpoints of ...

weaknesses so that the leader can boost their performance. The term was first used by Downton in 1973 but its establishment as an approach began with the publishment of James MacGregor Burns entitled "Leadership" (1978). In this work, he describes leaders as "people who tap the motives of followers in order to better reach leaders and followers aims" (pp. 18).

Transformal leadership is composed of the following core elements:

- Idealized influence (attribution) - form of charismatic leadership based on emotions and relations to admiration, respect and appreciation of dependents by the leader.

- Idealized influence (behavior) - form of leadership characterized by a behavioral activities related to feelings of admiration, respect and appreciation.

- Inspirational motivation - motivation to enhance a common view and to stimulate members of the organization to have a commitment that goes beyond the predicted tasks of the organization and providing staff with appropriate behaviors.

- Individualized consideration - intellectual stimulation provides new working forms associated by innovation and creativity.

With the charismatic leadership form, this form of leadership shares several similarities as: the significance of identification with leader and the consistence of leader's visions with all members of the organization. Research has shown that transformal leadership is an important defensive factor to the process of burnout in the health institutions and covers a positive impact on taking gratification from work and responsibility to organization.

Another argument on trasformal leadership was given by Bass (1998), who coined for the first time the concept of pseudotransformal leadership. The term is related to leaders who are self-consumed, exploitive and power oriented (Bass \& Riggio, 2006). Pseudotransformal leadership is considered as personalized that is focused in leaders' interests (Bass \& Steidlmeier, 1999).

Authentic transformational leadership is a socialized leadership in which leaders are generally concerned to the collective good and overshade themselves (Howell \& Avolio, 1993). Zhu, Avolio, Riggio and Sosik proposed a theoretical model that explained how authentic transformational leadership affects the ethics of followers and groups (2012: 3).

Authors assumed that authentic transformational leadership positively affects to moral identity and moral emotions that lead to the moral decision-making and moral enactment of their followers. Thus, this leadership subtype is positively associated to group ethical climate, decision-making and moral enactment. Leaders' authenticity is considered as significant as the authenticity of being and its Dasein. Psychodynamic study of the leadership process and the dynamical aspects of leader's personality are of great importance in the analysis and interpretation of this research. Childhood experiences and the patterns of child rearing affect the maturation and development of the individual.

These developed features of personality are closely integrated to each-other. The psychodynamic approach aims to explore the unconscious motives of leaders in their educational environment and their partners in the relation, students.

Krueger and Theusen emphasize that leadership involves the use of power and personality features of leader may comprise the way of reacting to difficulties, crisis situation and decision-making. 
In their study on identity development, Cote and Schwartz quote the research of Marcias (1980) on the argument. They posit a 3-dimensional field of maturity and self-regulation in the psychodynamic identity of leader.

- Identity diffusion, the least matured is characterized by a lack of direction and orientation to aims.

- Foreclose identity is much more mature and involve engagement.

- Moratorium identity takes proactive steps and aims the achievement of an autonomous self.

In the bottom of hierarchy stands Identity Achievement or the most matured state associated by the process of thought, interpersonal and social matured relationships (Cote \& Schwartz, 2002). In a psychodynamic sense, a leader with an achieved identity is the individual where libidinal and antilibidinal drives neutralize each-other for the sake of Ego.

We could speak therefore for an authentic leader with an achieved identity and Ego preservation as the teaching individual with the highest parameters of personality organization. The stability of neutral drives is the essence of a healthy personality organization and a positive behavioral trend for the teacher as a leader. In its primary purpose transformal leadership aims to improve the performance of its followers and to develop their complete potentials (Avolio, 1999; Bass \& Avolio, 1990a). This leadership type may be displayed by individuals who maintain a series of personal ideals and values and may motivate others to act in supporting the interest of all and not of one (Kuhnert, 1994). Promotion of this leadership style makes the leader (teacher or principal) to influence in understanding intra-psychic conflicts and empowering internal resources of students as consumers of lore and development. The first factor, idealized influence or charisma describes the emotional component of leadership (Antonakis, 2012). Leaders under the influence of this factor act as powerful models for their followers who identify with them and want to emulate their leader's model.

\section{Conclusions}

Recent research argue that teachers choose to stay in those educational institutions that provide opportunities for collaboration and shared leadership (Kirkpatrick \& Locke, 1991). Kilcher (1992) reasoned that when teachers feel valued as participants in a cohesive community and empowered as decision makers, they transmit this empowerment to their pupils and students by giving them a voice in decision making. It has already been argued that successful leadership in school requires a degree of administrative autonomy in decision-making for key elements of information entering the teaching process (Pont, Nusche \& Moorman, 2008). Teacher leadership, therefore, plays an important role in influencing compliant behavior aimed at encouraging and progressing learning and education structures with effective organization.

\section{Acknowledgements}

This research did not receive any specific grant from funding agencies in the public commercial, or not-for-profit sectors.

The authors declare no competing interests. 
E. Kafia, S. Ibrahimi \& E. Ibrahimi - Historical, Contemporary and Psychological Viewpoints of ...

\section{References}

Akerman, R., \& McKenzie, S. V. (2006). Uncovering teacher leadership. Educational Leadership, 63, 2499.

Ash, R. C., \& Persall, J. M. (2000). The principal as chief learning officer: Developing teacher leaders. NASSP Bulletin, 84, 15-22.

Bass, B. M. (1998). The ethics of transformational leadership. In J. Ciulla (Ed.), Ethics: The heart of leadership (pp. 169-192). Westport, CT: Praeger.

Bass, B. M., \& Avolio, B. J. (1990). The implications of transactional and transformational leadership for individual, team, and organizational development. Research in Organizational Change and Development, 4, pp. 231-272.

Bass, B. M., \& Steidlmeier, P. (1999). Ethics, character, and authentic transformational leadership behavior. Leadership Quarterly, 1O(2), 181-217.

Berne, E. (1963). The structure and dynamics of organizations and groups. Philadelphia: Lippincott.

Cote, J. E., \& Schwartz, S. J. (2002). Comparing psychological and sociological approaches to identity: identity status, identity capital, and the individualization process. Journal of Adolescence, 25, 571-586.

Dimmock, C., \& Walker, A. (2005). Educational leadership: Culture and diversity. Thousand Oaks, CA: Sage.

Freud, S. (1932). Introduzione alla psicoanalisi (nuova serie di lezioni). In Opere, Italian Edition., Vol. 11 (121-284). Boringhieri, Torino, 1979.

Freud, A. (1930). Quattro conferenze di psicoanalisi per insegnanti e genitori. In Opere 1922-1943, Italian edition, Vol. 1 (87-131). Boringhieri, Torino, 1978.

Getzel, J. W., \& Guba, E. G. (1957). Social behavior and the administrative process. The School Review, 65(4), 423-441.

Glickman, C., Gordon, S., \& Ross-Gordon, J. (2001). Supervision and instructional leadership: A developmental approach. Boston, MA: Ally \& Bacon.

Goleman, D. (2008). La pratica de inteligencia emocional. Spanish edition. Kairos.

Gonzales, L. D. (2004). Sustaining teacher leadership: Beyond the boundaries of an enabling school culture. Lanham, MD: University Press of America.

Harris, A., \& Muijs, D. (2005). Improving schools through teacher leadership. UK: MPG Books, Bodmin, Cornwall.

Howell, J. M., \& Avolio, B. J. (1992). The ethics of charismatic leadership: Submission or liberation? Academy of Management Executive, 6(2), 43-54

Kilcher, A. (1992). Becoming a change facilitator: The first-year experience of five teacher leaders. In C. Livingston (Ed.), Teachers as leaders evolving roles (pp. 91-114). Washington, D.C.: NEA Professional Library, National Education Association.

Kirkpatrick, S. A., \& Locke, E. A. (1991). Leadership: Do traits matter? The Executive, 5, 48-60.

Kriegel, U. (2009). Subjective consciousness: A self-representational theory. Oxford University Press.

Kurtines, W. M., Berman, S. L., Ittel, A., \& Williamson, S. (1995). Moral development: A co-constructivist perspective. In W. M. Kurtines \& J. L. Gewirtz, (Eds.), Moral development: An introduction (pp. 337-376). New York, Wiley. 
le Blanc, L. A., Bruce, L. C., Heimberg, R. G., Hope, D. A., Blanco, C. et al. (2014). Evaluation of psychometric properties of two short forms of the social interaction anxiety scale and social phobia scale. Assessment Journal, Sage Publication, 21(3), 312-313.

Lieberman, A., \& Miller, L. (1999). Teachers - transforming their world and their work. New York: Teachers College Press.

Leithwood, K., Jantzi, D., \& Steinbach, R. (1999). Changing leadership for changing times. Buckingham: Open University Press.

McGregor, D. (2006). The human side of enterprise - Annotated Edition, Second eds. Mc-Graw Hill Education.

Mumford, M. D., Zaccaro, S., Harding, F., Jacobs, T., \& Fleischman, E. A. (2000). Leadership skills for a changing world: Solving complex social problems. Leadership Quarterly, 11, 11-35.

Pont, B., Nusche, D., \& Moorman, H. (2008). Improving school leadership. Volume 1: Policy and practice. Directorate for Education. Education and Training Policy Division (OECD).

Quaglio, G. P. (2005). Leadership. Nuovi profili del leader per nuovi scenari organizzativi. Milano: Raffaelo Cortino ed.

Stech, E. L. (2007). Psychodynamic approach. In P. Northouse (Ed.), Leadership: Theory and practice (pp. 237-264). Thousand Oaks, CA: Sage.

Tannenbaum, R., \& Schmidt, W. H. (1958). How to choose a leadership pattern. Harvard Business Review, 36, 95-105.

Walumbwa, F. O., Avolio, B. J., Gardner, W. L., Wernsing, T. S., \& Petersson, S. J. (2008). Authentic leadership: Development and validation of a theory-based measure. Journal of Management, 34(1), 89-126; Southern Management Association, SAGE Publications. http://digitalcommons.unl.edu. 
E. Kafia, S. Ibrahimi \& E. Ibrahimi - Historical, Contemporary and Psychological Viewpoints of ...

C O A $\mathrm{s}$ 